Nauki ekonomiczne w XXI wieku - wyzwania, dylematy, perspektywy

ISSN 1899-3192

Międzynarodowe stosunki gospodarcze

\title{
Tadeusz Sporek
}

Uniwersytet Ekonomiczny w Katowicach

e-mail: tadeusz.sporek@ue.katowice.pl

\section{PRZEPLYWY KAPITALOWE \\ W FORMIE BEZPOŚREDNICH INWESTYCJI \\ ZAGRANICZNYCH WSPÓLCZESNYCH CHIN \\ W ASPEKCIE REGIONALNYM I GLOBALNYM}

\section{CHINA CAPITAL TRANSFER IN THE FORM OF FOREIGN DIRECT INVESTMENT - REGIONAL AND GLOBAL ASPECTS}

DOI: $10.15611 /$ pn.2017.498.30

JEL Classification: F12

\begin{abstract}
Streszczenie: Celem artykułu jest analiza przyczyn, wartości oraz kierunków bezpośrednich inwestycji zagranicznych Chin. Przyczyny inwestowania przez Chiny były zróżnicowane i zmieniały się w czasie. Należały do nich: aprecjacja yuana wobec dolara, wysoka stopa wzrostu realnych płac, nadwyżka handlowa Chin, która wywołała naciski partnerów handlowych na ograniczenie eksportu i podjęcie produkcji w ich krajach, wysoki poziom oszczędności wewnętrznych, niski poziom realnych stóp procentowych, wreszcie poszukiwanie tańszych miejsc pracy. Jeśli chodzi o wartość chińskich bezpośrednich inwestycji zagranicznych, zaczęła ona dynamicznie rosnąć od 2008 r. i trend wzrostowy trwa do dziś. Kumulacja nastąpiła w 2015 r. kiedy roczna wartość strumieni przekroczyła 145 mld dolarów. W XX i XXI wieku głównym odbiorcą inwestycji zagranicznych Chin zostały kraje azjatyckie, USA i kraje europejskie.
\end{abstract}

Słowa kluczowe: Chiny, bezpośrednie inwestycje zagraniczne, USA.

Summary: This article aims to analyze the causes, values and directions of foreign direct investments of China. There were several reasons to invest by China and they changed over time. These included: the strong apprecation of the yuan against the US dollar, the high rate of growth of real wages, the Chinese trade surplus, which caused the pressure of foreign partners to reduce exports and undertake the production in their countries, the abundance of capital in the domestic maret, the low level of real interest rates and finally the search for less expensive production sites. When it comes to the value of Chinese foreign direct investment, it began to grow rapidly in 2008, and the trend countinues till today. The pick occurred in 2015 when the annual value of the stream exceeded 145 billion dollars. In XX and XXI centuries the main recipients of the Chinese FDI were Asian countries, USA and the European states.

Keywords: China, foreing direct investment, USA. 


\section{Wstęp}

Przepływy kapitałowe, występujące zwłaszcza w postaci bezpośrednich inwestycji zagranicznych (BIZ), są elementem charakterystycznym dla współczesnej gospodarki światowej. Rezultatem postępującego procesu globalizacji jest integracja rynków finansowych, towarowych oraz globalnych zależności produkcyjnych, inwestycyjnych, a także technologicznych. Wszystko to powoduje, iż w swobodny sposób mogą przemieszczać się strumienie dóbr, kapitału czy też usług. Bezpośrednie inwestycje zagraniczne stanowią najbardziej pożądaną przez państwa formę transferu kapitału, wpływającą pozytywnie na rozwój gospodarek, szczególnie krajów słabo rozwiniętych i rozwijających się. Chińska Republika Ludowa stanowi doskonały przykład umiejętności wykorzystania szans, które niesie ze sobą internacjonalizacja i globalizacja. Jednym z najważniejszych filarów wzrostu Chińskiej Republiki Ludowej są właśnie BIZ. Prowadzona przez Chiny polityka otwierania się na zewnątrz stanowi codzienność dla korporacji transnarodowych Państwa Środka. Wciąż umacniają one swoją aktualną pozycję oraz docierają na nowe międzynarodowe rynki. Dodatkowo, kraj ten uznawany jest za atrakcyjne miejsce do lokowania zagranicznych inwestycji, za sprawą grupy wewnętrznych uwarunkowań składających się na klimat inwestycyjny państwa [Harach 2012, s. 91].

Głównym celem opracowania jest zaprezentowanie szczegółowej analizy w formie BIZ jako powiązań Chin z regionem i światem. Przeanalizowano kierunki napływu i odpływu kapitału, jak i źródła ich pochodzenia. Zwrócono uwagę na elementy klimatu inwestycyjnego oraz próbę zastosowania nowego modelu w chińskiej gospodarce, uwzględniającego handel zagraniczny i konsumpcję, która ma ułatwić przyspieszenie i wyprzedzenie supermocarstwa globalnego na świecie - gospodarki USA.

\section{Napływ kapitału w formie BIZ do kraju}

Atrakcyjność inwestycyjna państwa kształtowana jest przez wiele czynników ekonomicznych, prawnych, społecznych, politycznych, jak też infrastrukturalnych. Na początku należy poddać dogłębnej analizie warunki, które panują w danej gospodarce czy regionie, a dopiero później dokonać lokaty własnego kapitału. Bezpośrednie inwestycje zagraniczne napływające do Chin stanowią bardzo ważny element rozwoju kraju. Reformy dokonywane począwszy od 1978 roku spowodowały, iż państwo sukcesywnie otwierało się na świat oraz znacząco zwiększyło swoją pozycję w międzynarodowych stosunkach gospodarczych, stając się lokalnym oraz światowym liderem. Obecnie prawie wszystkie przedsiębiorstwa o globalnym zasięgu posiadają w Chińskiej Republice Ludowej swoje oddziały. Położenie geograficzne oraz zmiany dokonane w polityce gospodarczej kraju, polegające m.in. na zmniejszeniu cła, likwidacji kontyngentów importowych oraz modernizacji i restrukturyzacji gospodarki, wpłynęły na postrzeganie Chin jako atrakcyjnego miejsca do lokowania inwestycji. Dodatkowymi atutami kraju są duże zasoby taniej siły ro- 
boczej oraz ogromny rynek zbytu. Oprócz tego zauważalny jest bardzo szybki rozwój infrastruktury, a mianowicie rozbudowa sieci dróg, autostrad, szybkich kolei i lotnisk. Międzynarodowa pozycja Państwa Środka znacząco umocniła się dzięki przystąpieniu w 2001 roku do Światowej Organizacji Handlu (WTO). Co więcej ChRL jest członkiem wielu innych organizacji, np. Organizacji Narodów Zjednoczonych (ONZ), Międzynarodowego Funduszu Walutowego (IMF), Wspólnoty Gospodarczej Azji i Pacyfiku (APEC), UNCTAD oraz Stowarzyszenia Narodów Azji Południowo-Wschodniej (ASEAN), występując w nich jako partner dialogowy. Chiny oferują swoim potencjalnym inwestorom także przyjazne otoczenie biznesowe, ograniczoną biurokrację, a także preferencyjne warunki dokonywania inwestycji. Jednym z najważniejszych motywów podejmowania BIZ jest aktualna i prognozowana sytuacja ekonomiczna kraju goszczącego. Analizuje się w tym przypadku zwłaszcza wskaźniki oraz wielkości opisujące bieżącą sytuację gospodarki, jak też przewidywane ich zmiany, mogące wystąpić w długim okresie. Najważniejszą rolę odgrywają tutaj takie elementy, jak:

- tempo wzrostu gospodarczego państwa: głównymi jego źródłami są proeksportowa strategia rozwoju, inwestycje portfelowe i BIZ dokonywane na dużą skale oraz przyspieszony wzrost produktywności,

- wielkość stopy bezrobocia,

- poziom inflacji,

- rozmiar obrotów handlowych,

- struktura gospodarki [Harach 2012, s. 77-78].

Wybór miejsca lokalizacji inwestycji determinowany jest także przez klimat społeczny. Przede wszystkim bierze się tutaj pod uwagę rozmiary demograficzne oraz nakłady na naukę. Dostęp do wysokiej jakości kapitału ludzkiego jest dla potencjalnych inwestorów bardzo ważny. Z roku na rok zwiększa się poziom wykształcenia społeczeństwa chińskiego, co odzwierciedla fakt, iż duża liczba studentów podejmuje edukację poza granicami swojego państwa. Polityka przyciągania bezpośrednich inwestycji zagranicznych do kraju realizowana jest zwłaszcza poprzez odpowiednie przepisy prawne, odnoszące się do możliwości prowadzenia aktywności gospodarczej przez zewnętrzne podmioty, a także gwarantowanie bezpieczeństwa i równowagi inwestycji. Znaczącym czynnikiem atrakcyjności inwestycyjnej ChRL jest również pozytywne nastawienie lokalnych władz do napływu zagranicznego kapitału, przejawiające się licznymi systemami zachęt dla inwestorów, np. ulgami podatkowymi, subsydiami czy kredytami rządowymi [Harach 2012, s. 78-86]. Badania przeprowadzone przez Ernst \& Young, dotyczące atrakcyjności inwestycyjnej państw, wskazują, iż w 2014 roku najlepszym miejscem do lokowania kapitału okazała się Europa Zachodnia (45\% wskazań). Na drugim miejscu uplasowały się Chiny (44\% głosów respondentów). Liczba ta spadła o 1 punkt procentowy w porównaniu z rokiem poprzednim. Na dalszych miejscach znalazły się Ameryka Północna oraz Europa Środkowo-Wschodnia - kolejno 31\% i 29\% wskazań. Zależności pokazane zostały na rysunku 1. 
Raport sporządzony przez UNCTAD zawiera zestawienie państw, które stanowią wiodące lokalizacje BIZ z punktu widzenia korporacji transnarodowych w latach 2014-2016. Na czele klasyfikacji znalazły się Chiny.

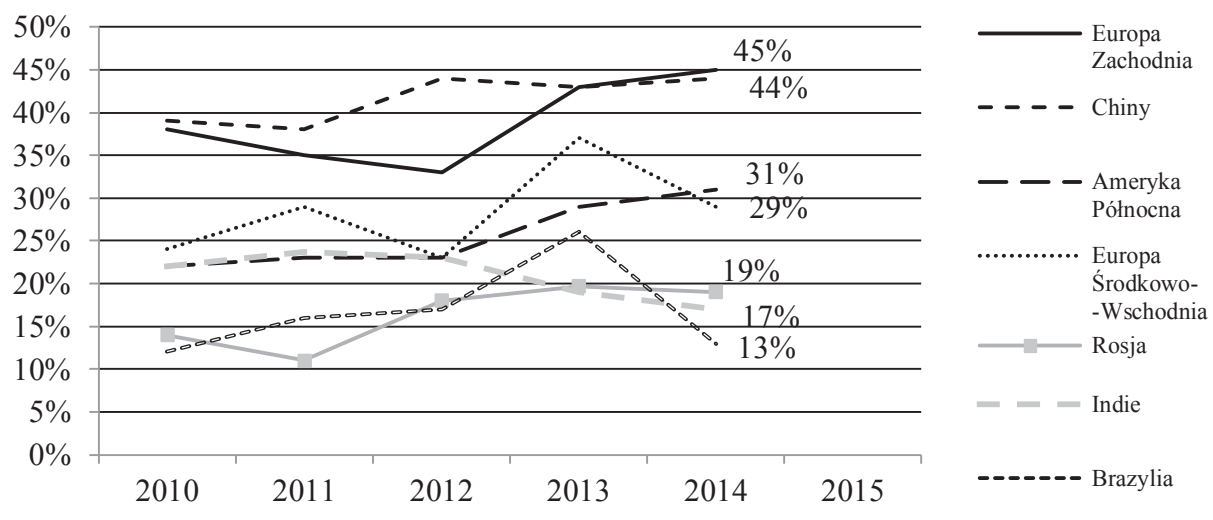

Rys. 1. Najatrakcyjniejsze na świecie regiony dla podejmowania BIZ w latach 2010-2015 (w \%)

Źródło: opracowanie własne [EY’s attractiveness survey Europe 2014].

Kraj ten zdaniem dominującej liczby opiniodawców pozostanie przodującą gospodarką, ku której skierują się strumienie bezpośrednich inwestycji. ChRL wyprzedza tym samym takie państwa, jak: Stany Zjednoczone, Indonezja, Indie, Brazylia czy Niemcy, co pokazuje rysunek 2.

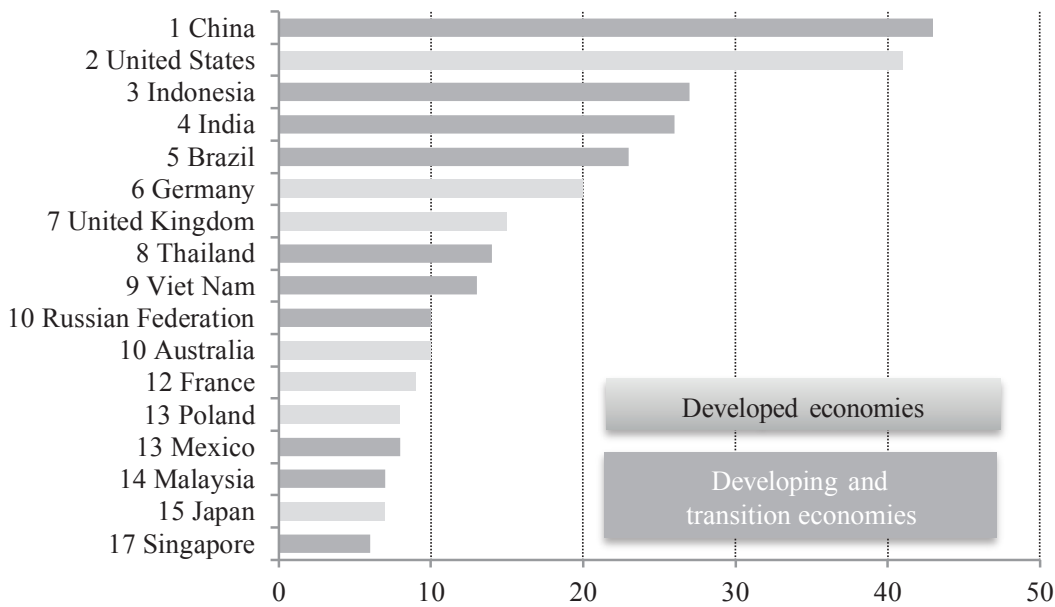

Rys. 2. Główne lokalizacje BIZ na świecie według KTN w latach 2014-2016 (\%)

Źródło: [World Investment Report 2014]. 
W latach 1979-1983 do Chin zaczęły napływać pierwsze inwestycje zagraniczne, których wartość wynosiła 1,8 mld USD. Były one skierowane głównie ku strefom ekonomicznym w prowincjach Fujian oraz Guangdong [Starzyk 2009, s. 229-234]. W momencie pojawienia się możliwości dokonywania lokat kapitału poza strefami, po 1984 roku znacznie wzrosło tempo inwestycji, zwłaszcza w latach 1992-1998. Z powodu wystąpienia kryzysu finansowego napływ BIZ w kolejnych latach zmniejszył się. Ponowne przyspieszenie miało miejsce w 2001 roku, kiedy to ChRL przystąpiła do WTO. Skutkiem tego było zlikwidowanie części ograniczeń dla zewnętrznych lokat, co wpłynęło na wzmożenie transferu kapitału do państwa. Wówczas wartość ta wynosiła ok. 47 mld USD. Tendencja rosnąca utrzymywała się aż do 2008 roku [Sporek 2012, s. 124]. Import BIZ do Chin równał się wtedy 108,3 mld USD. W 2009 roku zaobserwowano spadek do 95 mld USD. Za główną przyczynę tego zjawiska uznaje się problemy koncernów międzynarodowych wynikające $\mathrm{z}$ kryzysu finansowego. Pojawiły się w tym czasie liczne przeszkody w pozyskaniu kredytów, wzrosło ryzyko inwestycyjne, a co więcej - przedsiębiorstwa osiągnęły znacznie niższe zyski [Kostecka 2010, s. 309]. Po tym okresie można zauważyć znaczną poprawę w napływie strumieni BIZ do Chin, odzwierciadlającą się we wzroście ulokowanego tam kapitału. Największą jak dotąd wartość zaobserwowano w 2011 i 2013 roku (ok. 124 mld USD), a strategiczny przełom nastąpił w roku 2015, wtedy wartość inwestycji podmiotów zagranicznych w Chinach przekroczyła 135 mld USD [China ODI surpased FDI 2016]. Rysunek 3 przedstawia strumienie bezpośrednich inwestycji zagranicznych napływających do Chin w latach 1990-2015.

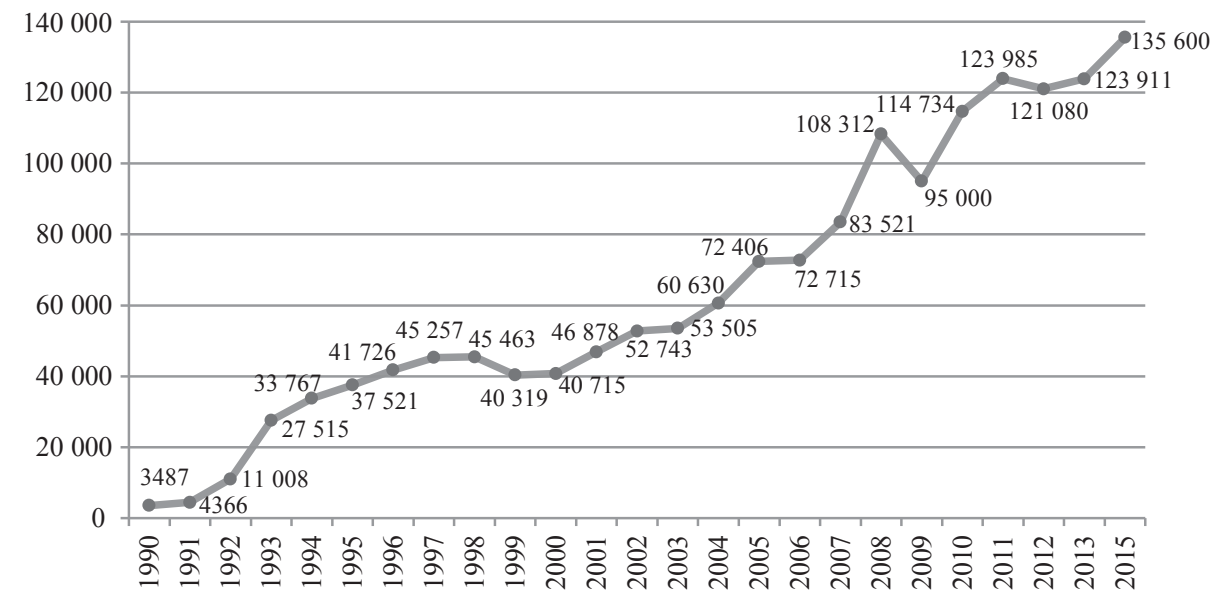

Rys. 3. Napływ strumieni BIZ do Chin w latach 1990-2015 (mln USD)

Źródło: opracowanie własne [Inward and outward foreign direct investment flows, annual, 1970-2013]. 
Wpływ zagranicznego kapitału na państwa goszczące w dużej mierze zależy od kraju, z którego wywodzi się inwestor. Strumienie BIZ pochodzące z rozwiniętych gospodarek dają możliwość skutecznego wyrównywania pojawiających się różnic rozwojowych. Bezpośrednie inwestycje zagraniczne mogą również zmniejszać regionalne dysproporcje, ale także na ich intensyfikację [Harach 2012, s. 87]. Analiza struktury przestrzennej napływających do Chin BIZ została zaprezentowana na rysunku 4. Od wielu lat największym inwestorem jest Hongkong. Dane statystyczne przedstawione przez Ministerstwo Handlu Chińskiej Republiki Ludowej pokazują, iż to właśnie stamtąd pochodzi aż 70,16\% ulokowanego w ChRL kapitału. Na kolejnych miejscach uplasowały się państwa, takie jak: Singapur, Tajwan, Japonia czy Korea Południowa.

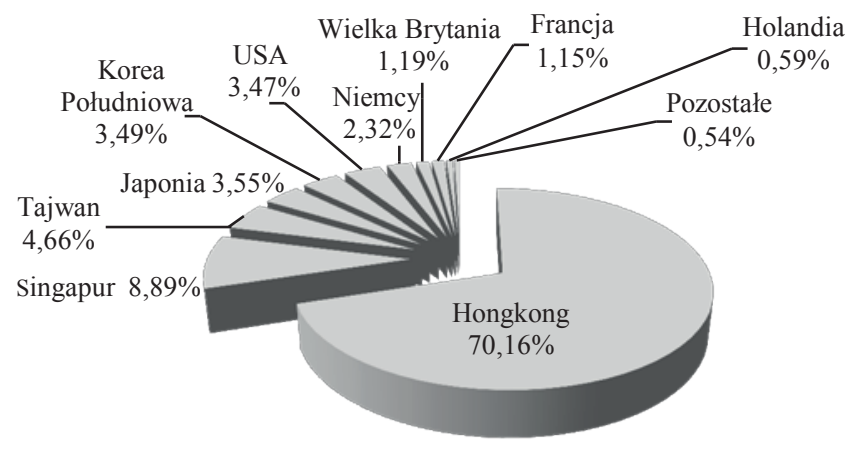

Rys. 4. Struktura przestrzenna BIZ napływających do ChRL w 2015 roku (w \%)

Źródło: opracowanie własne [Statistics... 2014].

Struktura sektorowa napływających do Chin strumieni kapitału zagranicznego w postaci BIZ ulega ciągłym przekształceniom. Zanim państwo przystąpiło do WTO, inwestorzy zewnętrzni zainteresowani byli głównie przemysłem przetwórczym, a w szczególności jego pracochłonnymi działami (tekstylia, odzież). Prócz tego lokaty dotyczyły także działów gospodarki powiązanych z surowcami, nieruchomościami, handlem oraz budownictwem [Sporek 2011, s. 155-164]. Bezpośrednie inwestycje zagraniczne skupiały się na produkcjach prostych, które nie wymagają nowoczesnych rozwiązań technologicznych. Po 2001 roku w większym stopniu zaczęto zwracać uwagę na produkcje kapitałochłonne [Cieślik 2012, s. 63]. $\mathrm{Z}$ danych przedstawionych przez National Bureau of Statistics of China wynika, iż w 2014 roku najwięcej inwestycji ulokowanych zostało w handlu hurtowym i detalicznym - 7349 lokat. Na kolejnych pozycjach znalazły się produkcja przemysłowa, a także leasing i usługi biznesowe, kolejno 6504 oraz 7349 inwestycji. Z kolei najmniejsza ich ilość dotyczyła sfery zdrowotnej, ubezpieczeń publicznych, opieki społecznej, jak też edukacji. 


\section{Odpływ strumieni BIZ z Chin}

Ważnym etapem z punktu widzenia chińskich korporacji transnarodowych była aprobata polityki go global przez najwyższe władze kraju. Chodziło tutaj o wspieranie lokalnych podmiotów w ich zagranicznej działalności. Skutkiem tego jest utrzymujący się od 2002 roku wzrost wartości BIZ odpływających z państwa. Pomimo wdrożenia licznych zachęt i ułatwień skłaniających do zagranicznej ekspansji kapitałowej, projekty realizowane przez przedsiębiorstwa ChRL podlegają ścisłej kontroli władz, która nadzoruje zewnętrzną aktywność tych podmiotów. Nawet prywatnie jednostki starają się zdobyć przychylność rządu dla swoich inicjatyw. Głównym organem sprawującym opiekę nad odpływem BIZ jest State Administration of Foreign Exchange (SAFE). Firmy państwowe dodatkowo kontroluje także State-owned Assets Supervision and Administration Commission (SASAC), która każdorazowo udziela zgody przedsiębiorstwom na inwestycje nienależące do podstawowej sfery działania firmy. Ponadto istotną rolę odgrywa Państwowa Komisja Rozwoju i Reform, wydająca instrukcje odnośnie do wychodzących na zewnątrz BIZ [Klimek 2014, s. 177].

Wartość chińskich inwestycji zagranicznych na świecie zwiększyła się w latach 1980-1990 o 1,85 mld USD [Sporek 2012, s. 127]. Począwszy od 1990 do 2004 roku eksport kapitału utrzymywał się na stosunkowo niskim i stabilnym poziomie w porównaniu z napływem BIZ z analogicznego okresu. Dopiero akcesja do WTO, zmiany uregulowań prawnych oraz wdrożenie strategii mających na celu promowanie za granicą chińskiego kapitału, przełożyły się na rozpoczęcie dokonywania lokat poza krajem macierzystym przez chińskie korporacje [Cieślik 2012, s. 61]. W ostatnich dziesięcioleciach zauważyć można bardzo dynamiczne ożywienie przepływów inwestycji zagranicznych. W 2003 roku wartość eksportowanego kapitału wynosiła ok. 2,9 mld USD. W roku 2013 jego wartość zwiększyła się aż do 101 mld USD, a przełom nastąpił w 2015 roku. Wtedy chińskie inwestycje zagraniczne osiągnęły 145,7 mld dolarów i zdominowały wartość inwestycji w Chinach, co po raz pierwszy w historii uczyniło z tego kraju eksportera netto [Wnukowski 2017, s. 5]. Przedstawione zależności ukazuje rysunek 5.

Dominującą lokalizacją chińskich bezpośrednich inwestycji zagranicznych są kraje azjatyckie. Trafia tutaj aż 67,7\% kapitału, który lokowany jest przez korporacje Państwa Środka za granicą. Na kolejnej pozycji znajdują się państwa Ameryki Łacińskiej przyjmujące ok. 13\% ogólnej wartości BIZ odpływających z Chin. Na trzecim miejscu uplasowały się kraje europejskie, posiadające ok. $8 \%$ udział. Chińczycy zaczynają dostrzegać potencjał Unii Europejskiej, jeżeli chodzi o możliwości inwestycyjne, a co za tym idzie - stopniowo zwiększają swoją obecność na tutejszych rynkach. Rysunek 6 obrazuje te relacje.

Największa liczba inwestycji zagranicznych ChRL, jeżeli weźmiemy po uwagę wartość przeprowadzanych transakcji, dokonywana jest w Hongkongu, na Kajmanach oraz w Stanach Zjednoczonych. Dokładniejsza analiza struktury geograficznej 


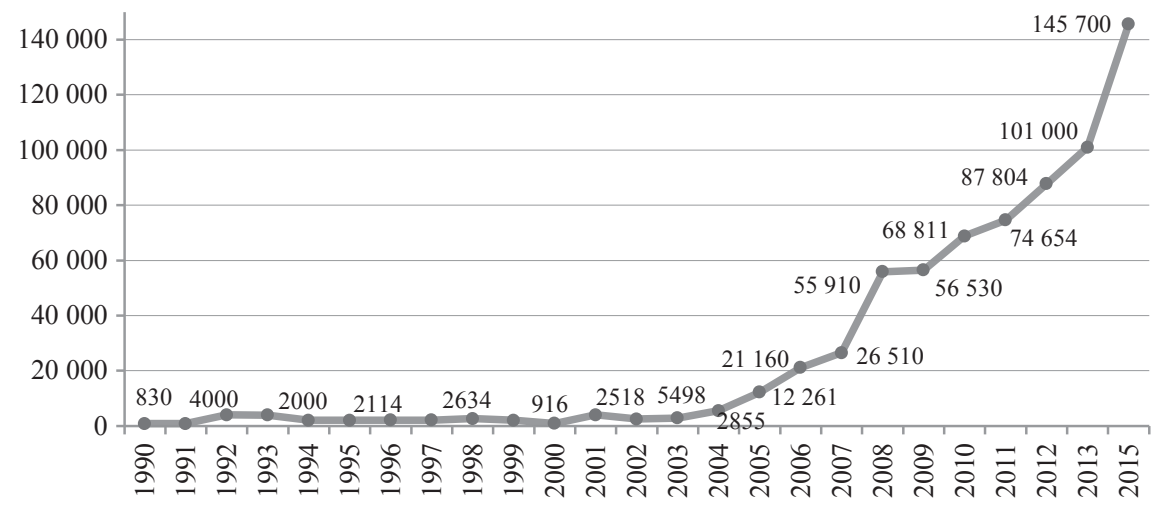

Rys. 5. Odpływ strumieni BIZ w latach 1990-2015 (mln USD)

Źródło: opracowanie własne [Inward and outward foreign direct investment flows, 1970-2013].

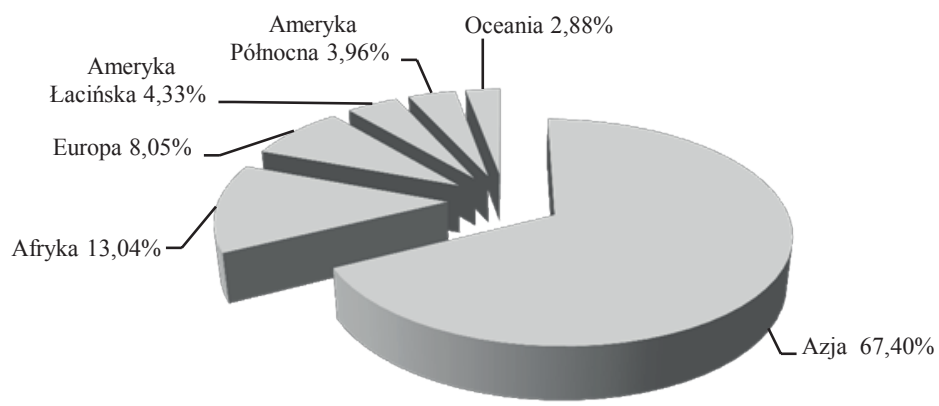

Rys. 6. Struktura geograficzna zasobów chińskich BIZ na koniec 2015 roku (w \%)

Źródło: opracowanie własne [Oversea Direct Investment by Countries or Regions, China Stastistical Yearbook 2014].

pokazuje, że przedsiębiorstwa chińskie inwestują najwięcej w Hongkongu (ok. 57\% ogółu wypływających BIZ). Pozostałe państwa cechują się znacznie mniejszym udziałem w omawianych przepływach. Kolejne miejsca wśród znaczących odbiorców kapitału zajęły Kajmany oraz Wyspy Dziewicze (6,4\% i 5,1\%), które zaliczane są do tzw. rajów podatkowych.

Dane opisujące strukturę branżową chińskich BIZ udowadniają, iż najbardziej popularnym kierunkiem inwestycji tutejszych korporacji w 2013 roku okazała się produkcja przemysłowa. Ten dział gospodarki zgromadził niemal $40 \%$ ogółu lokat przedsiębiorstw. Drugim popularnym obszarem były nieruchomości. Zainwestowano tutaj ok. 24,5\% całości kapitału odpływającego z kraju. Na trzecim miejscu znalazł się handel hurtowy i detaliczny posiadający ok. 10\% udział w zagranicznych zasobach BIZ. Ponadto ważną pozycję zajmowały również: leasing i usługi bizneso- 
we oraz transport, składowanie, usługi pocztowe. W trakcie okresu przyśpieszonego wzrostu gospodarczego Chin korporacje zgromadziły duże finansowe nadwyżki, które lokowane są poza granicami własnego państwa w wielu sektorach.

Sytuacja na rynku kapitałowym Europy zmienia się od 2010 roku. W imporcie BIZ od 2011 roku inwestycje Chin w Europie są większe niż w USA. Gwałtowny wzrost napływu chińskich BIZ zaczyna się po światowym kryzysie finansowym, a w 2015 roku wzrósł w Europie już do 20 mld euro. Większość tych pieniędzy wydały korporacje międzynarodowe i fundusze kontrolowane przez rząd Chin [Bryła 2017].

Chińscy inwestorzy postrzegają obecne osłabienie Europy jako okazję do wykonywania i zastosowania własnej technologii, polityki know-how, marek o dużej wartości.

Według analiz MERICS/Rhodium w pierwszej połowie dekady września 2017 roku Chińczycy w Europie najwięcej zainwestowali w Wielkiej Brytanii (15,2 mld euro) we Włoszech (11,2 mld euro), Francji (9,5 mld euro). Czwarte miejsce (7,9 mld euro) zajmowały Niemcy. Zdaniem analityków to właśnie Niemcy są krajem szczególnie atrakcyjnym w UE dla inwestorów z Chin.

Chińczycy kupili udziały między innymi w elektrowni atomowej na Wyspach Brytyjskich i w Deutsche Banku. Po tych decyzjach w Niemczech, we Francji i Włoszech rosną obawy przed nieograniczoną dostępnością dla chińskiego kapitału i pojawiła się propozycja blokowania ich przejęć w wybranych branżach, które dla wymienionej grupy mają strategiczne znaczenie [Bryła 2017; Omachel 2017].

\section{Zakończenie}

Stany Zjednoczone odgrywały główną rolę do kryzysu finansowego zapoczątkowanego na przełomie 2006/2007 roku na arenie międzynarodowej. Od przełomu XX i XXI wieku zasadność czy też efektywność tego przywództwa coraz częściej poddaje się rozważaniom z powodu narastających komplikacji oraz pojawiających się zewnętrznych i wewnętrznych wyzwań. Jednak biorąc pod uwagę tradycyjne mierniki mocarstwowości, m.in. kwestie militarne, technologiczne, ekonomiczne, a także finansowe, USA wciąż nie mają sobie równych. Kraj bezsprzecznie dysponuje największą gospodarką narodową, najbardziej zaawansowaną i innowacyjną technologią oraz najwyższym finansowym wpływem. Budżet wojskowy państwa jest znacznie większy aniżeli w innych państwach, a siły zbrojne, zlokalizowane są na całym świecie, posiadają zdolność szybkiej i natychmiastowej reakcji [Brzeziński 2013, s. 33]. We współczesnym środowisku międzynarodowym głównymi pretendentami do zdobycia pozycji hegemona są Chiny. Przyjęta przez ten kraj strategia działania wpisuje się w zaproponowaną przez Chiny w 2013 roku budowę Nowego Jedwabnego Szlaku, zakładającą promowanie na arenie międzynarodowej. Powiązane jest to z chińskimi aspiracjami do budowy potęgi morskiej, rewitalizacji korytarzy energetycznych i handlowych wspomagających przekształcenie się Chin w mocarstwo globalne [Small 2015, s. 1-2; Hu 2017]. Jeżeli Chińczycy utrzymają swoją 
dotychczasową pozycję, unikną groźnych wstrząsów społecznych i ekonomicznych, mają szansę zostać największym rywalem Stanów Zjednoczonych w starciu o polityczne wpływy, a także przywództwo gospodarcze oraz militarne na świecie [Brzeziński 2013, s. 78].

\section{Literatura}

Bryła E., 2017, Czy mamy szanse na chiński węzet, Rzeczpospolita, 15.09.

Brzeziński Z., 2013, Strategiczna wizja. Ameryka a kryzys globalnej potęgi, Wydawnictwo Literackie, Kraków.

China ODI surpassed FDI for the first time in 2015, KPMG, http://home.kpmg.com (29.09.02016)

Cieślik E., 2012, Efekt smoka. Skutki ekspansji gospodarczej Chin po 1978 roku, Wydawnictwo CeDeWu, Gdańsk.

EY's attractiveness survey Europe 2014. Back in the game, http://www.ey.com/Publication/vwLUAssets/EY-2014-european-attractiveness-survey/\$FILE/EY-2014-european-attractiveness-survey. pdf (2.03.2015).

Ernst \& Young's attractiveness survey, Europe 2013, Coping with the crisis, the European way, http:// www.ey.com/Publication/vwLUAssets/European-Attractiveness-survey-2013/\$FILE/European-Attractiveness-Survey-2013.pdf (3.03.1015).

Ernst \& Young's, 2012 European attractiveness survey, Growth actually http://www.eyeim.com/pdfE\&Y\%20European\%20survey\%202012.pfd (3.03.2015).

Góralczyk B., 2012, Chiny spowolnione czy zakręcone?, MojeOpinie.pl, 3 marca, http://mojeopinie.pl/ prof_goralczyk_chiny_spowolnione_czy_zakręcone,3,1331664441 (7.04.2015).

Harach M.E., 2012, Bezpośrednie inwestycje zagraniczne w Chińskiej Republice Ludowej - analiza uwarunkowań, skali oraz struktury napływu BIZ, [w:] Kantorowicza A. (red.), Azja w gospodarce światowej - inwestycje, produkcja, handel, Wydawnictwo Uczelni Vistula, Warszawa.

Hu B., 2017, Chiny sa gotowe do nowych ról, Rzeczpospolita, 28.06.

Inward and outward foreign direct investment flows, annual, 1970-2013, http://unctadstat.unctad.org/ wds/TableViewer/tableView.aspx (5.03.2015).

Klimek A., 2014, Korporacje transnarodowe z krajów wschodzacych w gospodarce światowej. Wydawnictwo Uniwersytetu Ekonomicznego we Wrocławiu, Wrocław.

Kostecka L., 2010, Bezpośrednie inwestycje zagraniczne w gospodarce Chin, [w:] Marszałek-Kawa J. (red.), Chiny supermocarstwem XXI wieku? Rozważania na temat polityki i gospodarki państwa środka, Wydawnictwo Adam Marszałek, Torun.

Omachel R., 2017, Wejście smoka, Polityka, 25.09 - 1.10.

Oversea Direct Investment by Countries of Regions. China Statistical Yearbook 2014, http://stats.gov. $\mathrm{cn} / \mathrm{tjsj} / \mathrm{ndsj} / 2014 / \mathrm{zk} / \mathrm{html} / \mathrm{Z1116E}$.xls (20.03.2015)

Small A., 2015, The China - Pakistan Axis: Asia's, New Geopolitics, Oxford University Press.

Sporek T., 2011, Chińska Republika Ludowa - główny partner handlowy Unii Europejskiej, Studia Ekonomiczne, Uniwersytet Ekonomiczny w Katowicach, nr 90.

Sporek T., 2012, Region Azji najatrakcyjniejszym, choć ryzykownym miejscem lokowania BIZ na świecie $w$ XXI w. Prace Naukowe, Uniwersytet Ekonomiczny w Katowicach.

Statistics of FDI in China in January-September 2014.

Starzyk K., 2009, Zagraniczna polityka ekonomiczna w procesie rynkowej transformacji gospodarki. Przypadek Chin, Wydawnictwo Placet, Warszawa.

Wnukowski D., 2017, Chiński dylemat polskiej polityki zagranicznej, Polski Przegląd Dyplomatyczny, nr 3. World Investment Report, 2014, htpp://unctad.org/en/publicationslibrary/wir2014_en.pdf. (5.02.2015). 